Marquette University

e-Publications@Marquette

$3-1-2000$

\title{
Weight Discrimination: A Multidisciplinary Analysis
}

Cheryl Maranto

Marquette University, cheryl.maranto@marquette.edu

Ann Fraedrich Stenoien

Marquette University

Accepted version. Employee Responsibilities and Rights Journal, Vol. 12, No. 1 (March 2000): 9-24. DOI. (C) 2000 Springer. Used with permission.

Shareable Link. Provided by the Springer Nature SharedIt content-sharing initiative. 


\title{
WEIGHT DISCRIMINATION: A MULTIDISCIPLINARY ANALYSIS
}

\author{
Cheryl L. Maranto ${ }^{1}$
}

Ann Fraedrich Stenoien

${ }^{1}$ Department of Management, Marquette University, P.O. Box 1881, Milwaukee, WI 53201-1881, MARANTO@MAIL.BUSADM.MU.EDU. (414) 288-1441. 


\begin{abstract}
Protection against obesity discrimination is extremely limited under the Americans with Disabilities Act (ADA). No obese plaintiff has won using the actual disability theory, but a few have won under the "perceived disability" theory. Weight-related appearance standards are legal.

We estimate weight-based wage penalties for young men and women. We find that mildly obese (20\% over standard weight) white women experience greater wage penalties than black men experience for weight that is $100 \%$ over standard weight. Men do not experience wage penalties until their weight exceeds standard weight by over 100 pounds. A "gender-plus" analysis under Title VII is more appropriate than the ADA for addressing the weight-based wage penalties that women experience.
\end{abstract}

Key words: weight discrimination, obesity, gender-plus discrimination, sex differences, wage differentials 


\section{INTRODUCTION}

Do obese or overweight individuals experience employment discrimination? If so, are they protected under anti-discrimination laws? These questions have been asked with increasing frequency since the Americans with Disabilities Act (ADA) went into effect in 1992. Some articles in non-law journals were written before significant case law developed on the issue (e.g., McAdams, Moussavi and Klassen, 1992). Others lack precision concerning the likelihood and extent of protection that is available (Paul and Townsend, 1995; Laabs, 1995). The legal literature conveys the nuances and limitations of legal protection against obesity discrimination, but provides no empirical evidence of the extent to which such discrimination exists. Empirical studies of discrimination against the obese use medically-based definitions of obesity that have no relation to the level that is protected under the ADA or the Rehabilitation Act (e.g., Averett and Korenman, 1996; Register and Williams, 1990), and some imply far greater legal protection than what is generally available. For example, "Anti-discrimination legislation has been enacted in the U.S. to prevent denying employment on the basis of height, weight and personal appearance." (Hamermesh and Biddle, 1994, p. 1174).

We attempt to address these limitations by adopting a broad, multidisciplinary approach. We review the findings in the medical and psychology literature regarding obesity, and compare them to the legal standards that have been developed in EEOC guidelines and case law under the Rehabilitation Act and the ADA. We estimate the wage effect of weight relative to height (BMI) and alternative definitions of obesity for men and women, controlling for productivity and other wage determinants. The weights at which wage penalties begin are compared to the weights at which legal protection may be available under the ADA. An alternative approach for obtaining legal protection is proposed. Evidentiary obstacles to this approach are noted. 


\section{OBESITY AS A PROTECTED DISABILITY}

\section{Definitions of Obesity}

Before determining whether obesity is a protected status, it is first necessary to define the term. "[S]ince the amount of body fat, as estimated by various indices, is a continuous variable within the population, all quantitative definitions of obesity must be arbitrary" (National Institutes of Health, 1985). Various levels of obesity are recognized, based on the percentage by which weight exceeds the "norm" for one's height. These norms are based on actuarial tables developed by Metropolitan Life Insurance Company of New York for policy holders in 1983, and indicate the weights at which mortality rates are minimized (Metropolitan Life Foundation Statistical Bulletin, 1983). These norms are significantly below average weights in the U.S., and are based on a sample which is primarily white and affluent, while average weight varies significantly by race and socioeconomic status. A body weight 20 - 40 percent over the norm for one's height is mild obesity; a weight 41 - 99 percent over the norm is moderate obesity; and a weight 100 pounds or 100 percent over the norm is morbid obesity (Berkow et al., 1992).

A second set of definitions is based on nationally representative surveys of the population, known as the National Health and Nutrition Evaluation Survey (NHANES) I and II (Must, Gortmaker and Dietz, 1994). Obesity is defined as a body mass index or BMI (weight in kilograms divided by height in meters squared) greater than the gender-specific 85 th or 95 th percentile. BMI correlates strongly with skinfold tests (Must, Dallal and Dietz, 1991) and predicts disease (National Institutes of Health, 1985). For a comparison of these definitions, translated into pounds and BMIs, see Table 1.

\section{INSERT TABLE I HERE}

There is no consensus within the medical community of the appropriate definition 
of obesity (Calloway, 1987), and empirical studies of obesity's wage effects have utilized various definitions. "Although 'obesity is the most prevalent nutritional disorder in the Western world', moderate obesity is uncommon and morbid obesity is rare"' (Kuss, 1996).

\section{$\underline{\text { Legal Issues }}$}

The legal status of obesity as a protected disability under the Americans with Disabilities Act (ADA) has not been definitively established. The legislation itself does not directly address the issue of obesity, lower court decisions are contradictory on several key points, and the Supreme Court has not yet ruled on the question. Among the many state laws that protect against disability discrimination, only Michigan's law explicitly prohibits discrimination based on a person's weight, and Washington D.C. law prohibits discrimination based on personal appearance, which may include overweight (Ziolkowski, 1994).

The ADA prohibits discrimination against a qualified individual with a disability who, with or without reasonable accomodation, can perform essential job functions. To receive protection, an individual must first establish that they have a covered disability--either: (1) they have an actual physical or mental impairment that substantially limits one or more major life activities, or (2) the employer perceives them as having such a limiting impairment.

Under the "actual disability" theory, the first question to be determined is whether the individual has an impairment. An impairment is defined as "Any physiological disorder or condition, cosmetic disfigurement, or anatomical loss affecting one or more systems of the body" (BNA, 1995). This raises the question of what causes obesity.

... [T]his disease in man [sic] is complex and deeply rooted in biologic systems. Thus, it is almost certain that obesity has multiple causes and that there are different types of obesity" 
(NIH, 1985). On the most simplistic level, obesity results from excessive caloric intake relative to expenditure. This fact may be the source of the widely held assumption that overweight or obesity is simply caused by overeating (and/or too little exercise). Surprisingly, many medical studies have failed to document a positive relationship between people's weight and food intake (e.g., Sobal and Stunkard, 1989), and at least one such study found an inverse relationship (Calloway, 1987). Moderating the relationship between obesity and food intake are individual differences in metabolic rates (often inherited), as well as basic metabolic mechanisms, selected by survival during times of food shortages, such that when caloric intake is severely restricted, the metabolic rate decreases.

Lower courts have differed as to whether obesity by itself (without other medical conditions) should be considered an impairment under the law. EEOC Guidelines (which are accorded some deference, but are not binding on the courts) now automatically consider morbid obesity to be an impairment. However, the impairment must also constitute a disability, i.e., it must also substantially limit one or more major life activities, e.g., caring for oneself, performing manual tasks, walking, seeing, breathing, learning, or working. In order to be substantially limiting, a condition must be of long duration, or have permanent or long-term effects.

Substantial scientific evidence suggests that, regardless of how one becomes overweight, weight loss is difficult and often ends in failure. "If a 'cure' for obesity is defined as reduction to desired weight and maintenance of that weight for five years, it is more likely that a person will be cured of most forms of cancer than of obesity" (Council on Scientific Affairs, 1988, p. 2547). Despite such medical evidence, some courts have ruled that obesity is not a covered disability under the ADA because it is presumed to be mutable and voluntary (Garcia, 1995). 
Whether obesity constitutes a substantially limiting impairment also depends on whether it carries systematic and predictable medical consequences. "There is a continuous relationship between relative weight or BMI and morbidity and mortality ... an increase in body weight of 20 percent or more above desirable body weight constitutes an established health hazard" (NIH, 1985). On the other hand, numerous medical studies indicate that overweight, per se, is not directly related to health risk (e.g., Barlow, Kohl, Gibbons and Blair, 1995; Troiano, Frongillo, Sobal and Levitsky, 1996). How can these findings be reconciled? Several serious health conditions (e.g., hypertension, high cholesterol, diabetes and coronary artery heart disease) are correlated with obesity. However, it is the possession of these complications, or the risk of these complications (e.g., family history), rather than obesity per se that increases disease and death rates. In other words, these correlations do not indicate causation. The specific behaviors of high dietary fat and low levels of physical activity and aerobic fitness are the causal factors (Barlow et at., 1995; Blair, Kohl, Barlow, Paffenbarger, Gibbons and Micera, 1995). These behaviors are associated with obesity (a physical trait), but heredity is a major confounding factor. Lowering dietary fat and increasing exercise quickly reduce several medical risk factors, but can have minor effects on body weight (Paffenbarger, Hyde, Wing, Lee, Jung and Kampert, 1993). “ . . . metabollically fit individuals and healthy bodies come in all shapes and sizes. . " (Gaesser, 1996). In addition, location of body fat is an important predictor of health hazards, with the pear-shaped typically feminine distribution carrying relatively little health risk, compared to the abdominal, typically male distribution (NIH, 1985; Calloway, 1987). Thus, there is no necessary relationship between obesity and substantially limiting impairments. According to EEOC Guidelines, "[except] in rare circumstances, obesity is not considered a disabling impairment." 
To date, no plaintiff has successfully established that their obesity substantially limits a major life activity under federal law $^{2}$ despite, for example, an inability to walk in a commencement procession (e.g., Nedder v. Rivier College, 1996). However, the actual disability theory does not appear to be important for obesity discrimination in practice. "Often neither plaintiffs nor their physician consider their weight to be problematic or even relevant to their job performance. Obese plaintiffs maintain they are healthy. Genuine physical impairment often has little to do with the cause of the discrimination" (Hartnett, 1993, p. 825-6). The conclusion that obesity does not meet the requirements for ADA coverage as an actual disability is consistent with the medical evidence, though some courts have reached this conclusion for the wrong reasons.

The most promising legal development for protection against obesity discrimination involves the "regarded as impaired" or "perceived disability" theory. Several courts have interpreted state disability laws to require that a plaintiff have an actual impairment, even if they utilize the perceived disability theory. Using this analysis, these courts have rejected obesity claims because obesity does not meet the law's definition of an impairment (Cassista $v$. Community Foods, Inc., 1993; Civil Service Commission v. Pennsylvania Human Relations Commission, 1991 ). But according to EEOC guidelines, a person who does not have an actual disability can qualify for protected "disability status" if one of three conditions are met. The person has a physical or mental disorder that is not substantially limiting, but the employer regards the person as if it is substantially limiting. (2) The person has a physical or mental disorder that is substantially limiting only as a result of the attitudes of others. (3) The person has no disorder at all, but the employer treats him/her as if s/he had a physical or mental disorder that

\footnotetext{
${ }^{2}$ Obesity was found to be an actual disability in State Division of Human Rights v. Xerox (1985). The decision noted
} 
substantially limits a major life activity. Thus, according to the EEOC, a plaintiff does not have to prove a physiological cause or actual impairment, but s/he does have to prove that the employer thought the overweight condition was a physical impairment that substantially limits a major life activity. If the activity is working, the employer must indicate that s/he believes the individual is unable to perform a wide range of jobs, not just the job in question.

Although now over four years old, Cook v. Rhode Island Department of Mental Health $(1993)^{3}$ remains the only case regarding obesity discrimination that has reached a federal appellate court. The Cook court found that the plaintiff was illegally discriminated against due to her morbid obesity under the perceived disability theory. The Department's own doctor stated that her obesity prevented her from performing a wide range of jobs within the health care industry. But this opinion was not substantiated with medical evidence (in fact the "medical exam" consisted of watching the plaintiff walk across the room), Cook did not suffer from any serious medical condition often associated with obesity, and the job in question did not require significant physical activity. Thus by its own admission, the employer regarded Cook as substantially limited in her ability to work. Cook maintained that she did not have a disability, and she had worked for the Department previously in this job and had a flawless work record. The Cook court explicitly rejected the relevance of both the mutability and voluntariness of a disability as preventing coverage, noting that lung cancer and AIDS, among others, are covered disabilities to which an individual's behavior may contribute. This case is not binding precedent outside of the First Circuit.

that New York law does not require a finding of an actual impairment, but federal law does.

${ }^{3}$ Cook was brought under the Rehabilitation Act, but the statutory language is identical to the ADA, and is considered to be controlling precendent for the ADA. 
While the ability of even morbidly obese plaintiffs to obtain protection is not yet definitively established, the most recent case law under ADA is consistent with EEOC guidelines and Cook as to the requirements for coverage under the perceived disability theory. In EEOC v. Texas Bus Lines (1996) and Polesnak v. R. H. Management Systems (1997), U. S. district courts found that morbidly obese individuals were illegally denied employment and discharged, respectively, based on the employers' perception that their obesity was a disability, when in fact they were not disabled. In two other cases (Bryant v. Troy Auto Parts, 1997 and Nedder v. Rivier College, 1996), the employers' requests for summary judgement were denied and trials were ordered. The courts found that the plaintiffs were not be disabled, but they raised a question of fact as to whether the employer perceived that their morbid obesity constituted a disability. Although these latter cases have yet to be decided on their merits, these courts have adopted the EEOC's interpretation of the ADA that an individual need not have an actual impairment in order to be covered by the law.

Interestingly, one of the greatest risks for employer liability under the ADA arises from prejudicial attitudes of doctors. Despite the well-documented complexity of medical issues involving obesity, some of the most negative stereotypes of obese persons (e.g., as ugly and weak-willed) are widely shared in the medical community (DeJong, 1980)--they share a "lipophobic paradigm" (Gaessert, 1996). In two of the three cases in which employers have been found guilty of discriminating against obese plaintiffs (Cook v. Rhode Island, 1993; EEOC v. Texas Bus Lines, 1996), unfounded opinions of doctors have provided the evidence required to establish that the employer regarded the plaintiff as disabled.

Despite this legal breakthrough, coverage is still limited to morbid obesity, which is very rare. Thus, there are many people who are overweight by both medical and social standards who 
would not be protected from discrimination on the basis of their weight under available legal precedent. "For good or evil, private employers are generally free to be arbitrary and even capricious in determining whom too hire, unless the employer somehow discriminates on the basis of race, national origin, alienage, age, sex, or handicap status" (Tudyman v. United Airlines, emphasis added).

Limited legal protection does not make moot the question of whether obese or simply overweight individuals face discrimination in the labor market. Before we test for the existence of labor market discrimination based on weight, however, we review literature which documents widespread societal perceptions and attitudes that are likely to motivate discriminatory behaviors toward the obese or overweight.

\section{$\underline{\text { Social-Psychological Issues }}$}

"Of all the conditions for which a person may be stigmatized in our culture, including racial or ethnic group membership, religious affiliation, physical handicaps, and sexual preferences, the stigma of being overweight may be the most debilitating" (Allon, 1982). Common psychological reactions to obesity have been explained using Goffman's (1963) typology of stigmas--i.e., attributes which "spoil the identity of the individual possessors", who are viewed as "not quite human" (DeJong, 1980). The three types of stigma are "abominations of the body" or physical deformities; "tribal stigmata" such as race, religion and social class; and "blemishes of individual character", such as mental illness, addictions and homosexuality. Many studies document widely held extremely negative attitudes toward the overweight (e.g., Richardson, et al., 1961; Alessi and Anthony, 1969; Allon, 1982; Crandall and Biernat, 1990). For example, children asked to rank-order drawings of children with various physical disabilities (leg brace and crutches, confined to a wheel chair, hand amputee, facial disfigurement, and 
obesity) according to how much they like them, consistently rank drawings of the obese child last or next to last (De Jong, 1980). These attitudes may result from the fact that obesity carries two types of stigma: it is widely viewed as both an "abomination of the body" and a "blemish of character". In other words, overweight individuals are often blamed for their condition (e.g., Allon 1982), unlike individuals with other physical disabilities who often elicit sympathy.

\section{$\underline{\text { Demographic Issues }}$}

There are dramatic differences in the prevalence of obesity (however defined) across race/sex groups. Must, Gortmaker and Dietz (1994) estimate that the prevalence of obesity (85th percentile BMIs among 20-29 year olds based on the NHANES-I survey) varied from 14.5 percent of African-American men and 15.0 percent of white women, to 23.2 percent of Hispanic men and 27.6 percent of African-American women. Since, on average, all groups gain weight with age, and differences in prevalence also increase with age, these data understate the differences that exist in the entire adult population.

Social weight norms vary across societies and over time. While there is a consistent inverse relationship between socioeconomic status (SES) and the prevalence of obesity among women in developed societies, SES is just as consistently, but directly associated with the prevalence of obesity among women in developing societies (Sobal and Stunkard, 1989). Over the last 20 years, there has been an increase in height with stable weight for models, Miss America contestants and Playboy centerfolds. In other words, “ . . the cultural ideal has gotten thinner .. . “(Calloway, 1987, p. 29). Marilyn Monroe, after all, was a size 12.

Clearly attitudes toward people based on their weight are rooted in a particular social context. Obese plaintiffs' experience under the ADA suggests that the barriers faced by the obese are not due to physical or medical problems, but result from unfounded assumptions and highly 
negative stereotypes. In a carefully controlled experimental study, Larkin and Pines (1979) found that obese applicants were significantly less likely to be hired in a testing and hiring simulation. The actual (test scores) and perceived (the same videotaped hands) performance on a selection test were identical between obese and non-obese "applicants". When asked about the decision not to hire obese applicants, subjects cited perceived inadequacies in the obese applicant's personality or motivation, even though these decisions were based on viewing videotapes without audio (i.e., they did not have access to any relevant information for making such determinations).

There are significant differences in attitudes toward the obese, depending on an individual's gender. "Obesity is a severely stigmatized condition among women, and one of relative affective neutrality among men" (e.g., Sobal and Stunkard, 1989 citing Allon 1982; DeJong, 1980). Many women fear being fat more than they fear death (Crocker et al., 1993). In contrast to the societal consequences, gender differences in the medical consequences of obesity favor women. "The same amount of obesity in a woman is not as hazardous [to health] as the same amount of obesity in men", due to differences in typical fat distribution by gender (Calloway, 1987).

\section{Economic Effects of Obesity}

There is a growing literature that estimates the impact of obesity on wages. Register and Williams (1990) use 1982 data from the National Longitudinal Survey of Youth (NLSY), and define obesity as 20 percent or more above standard weight for height (i.e., mild obesity) using the Met Life tables. They find that obese women suffer a 12 percent wage penalty, but obese men do not. Loh (1993) focuses on the potential for wage differentials to be linked to productivity differences based on "appearance" as measured by weight (and height). He also uses 1982 NLSY data (18 to 25 year olds) to estimate the effects of a mild obesity dummy or a continuous linear 
relative weight variable (actual weight/standard weight) on the wages of full-time workers. Among men, the linear relative weight variable is positive and significant, and the obesity dummy is not significant. Sargent and Blanchflower (1994) use data on the entire birth cohort from one week in 1958 in England, Scotland and Wales to estimate the effects of obesity on wages at age 23. Obesity is defined as the 90th percentile BMI (which corresponds to the 85th percentile in the U.S.) and morbid obesity at the 99th percentile. They find that both current and lagged (BMI at age 16) obesity measures significantly reduce current wages (at age 23 ) of women, but not men. Averett and Korenman (1996) use data from the 1988 wave of the NLSY (age 23-31) to estimate the effects of obesity on wages (and other economic outcomes). A series of weight dummies, based on the Met Life tables (less than the recommended BMI, 20 percent over, and BMI of 30 or more, which is equivalent to the 95 th percentile) are used. They control for health limitations, intelligence test scores, and self-esteem, in addition to standard human capital variables. They find that very obese (over $30 \mathrm{BMI}$ ) women have significantly lower wages than standard weight women. White and Hispanic women suffer wage penalties due to obesity, but black women do not. For men, there is some evidence of significant wage penalties for both obesity and underweight, but these results are less consistent across samples and specifications.

\section{HYPOTHESES}

Our earlier review indicates that the ADA provides a possible source of protection against weight-based discrimination only for the morbidly obese (100 pounds or 100 percent over standard or "ideal" weight). Plaintiffs must prove that the employer perceived and acted on the assumption that their weight is an impairment that substantially limits their ability to work. Employers are unlikely to perceive mildly or even moderately obese individuals to be physically disabled. The social psychology literature suggests that highly negative stereotypes of the 
morbidly obese are widespread. Thus, we expect that morbid obesity has a negative effect on wages. The literature also suggests that social weight norms are becoming increasingly thin, which could generate discrimination at weight levels considerably below morbid obesity. Thus, we also expect that mild obesity has a negative effect on wages. Finally, we expect that weight has a negative effect on wages over the entire weight range, i.e., that "thinner is better", no matter how thin you already are.

Another question of relevance to discrimination law is whether there are significant differences in weight-based discrimination across gender or race. The medical literature suggests that obesity has a more detrimental health effect on men than women. If actual disability contributes to lower productivity, we would expect men to suffer greater penalties for obesity than women. The social psychology literature suggests that obesity carries a much greater stigma for women than men (at least at weights below morbid obesity). Thus, if societal attitudes or norms of "beauty" are the primary cause of discrimination based on weight, we would expect women to experience greater weight-based wage penalties than men, at relatively low levels of overweight (i.e., mild obesity). The facts that have been presented in obesity discrimination cases suggest that actual disability is not a major problem for obese workers. Thus, we expect to find greater wage penalties for women than men. Although there are significant race differences in obesity prevalence by race, the social psychological literature is silent on differences in attitudes toward obese individuals based on race. Thus, we have no a priori expectations regarding race differences in weight-based wage penalties. 


\section{METHODS}

$\underline{\text { Data }}$

We use data from the 1988 wave of the National Longitudinal Survey of Labor Market Experience of Youth (NLSY), when respondents were 23 to 30 years old. The 12,686 respondents were first interviewed in 1979, and have been re-interviewed every year since. Blacks, Hispanics and economically disadvantaged white youth were over-sampled to allow for meaningful tests of race differences. The survey contains detailed information on the respondents' families, attitudes, school history, income, work history and aspirations.

Data on the respondents' height were collected in the 1981, 1982 and 1985 surveys. Comparing the data across the three years reveals several different patterns. When normal growth patterns were observed (the majority of respondents), the height reported in 1985 was used. Decision rules were developed to deal with anomalous height patterns (i.e., loss of height over the three years, an increase of more than 7 inches in one year or more than 9 inches over 4 years, and missing values). ${ }^{4}$ Weight as reported in 1988 was used. Observations with missing data resulting from invalid skips, refusals and "don't know" answers were eliminated. This resulted in samples of 3,393 men and 3,208 women. We use data from the 1988 survey, in order to replicate and compare results to previous studies. Table II reports the names and definitions of the variables used in the analyses.

\section{INSERT TABLE II HERE}

\footnotetext{
${ }^{4}$ If one value was missing and the other two were not the same, but there was not a reduction in height, the mean of the two values was used. If 1981 height was greater than 1982 height and equal to 1985, the 1982 height was used. If 1982 height was greater than 1985 height, and 1981 height was equal to 1985 height, the 1985 height was used. If 1981 height was greater than 1982 or 1985 height, or if 1982 height was greater than 1985, and the other two heights were unequal, the average of the three heights was used.
} 


\section{$\underline{\text { Model }}$}

We estimate the natural log of the hourly wage using regression analysis. ${ }^{5}$ In order to estimate the independent effect of relative weight on wages, it is necessary to control for known productivity determinants. Thus, standard human capital variables (education, work experience, tenure with the current employer and tenure squared) are included. All are expected to have a positive impact on wages, except tenure squared, which is expected to have a negative effect. We also control for two productivity determinants that are correlated with obesity. Respondents were asked whether health limits the kind or amount of work he or she can do. This is expected to have a negative effect on wages. Intelligence (measured by the Armed Forces Qualification Test score) is expected to have a positive effect on wages. Documented institutional influences on wages are also included: region of residence (South is the excluded category), residence in a metropolitan area, coverage by a collective bargaining agreement, large firm (over 500 employees), capital intensive industry and occupational status, all of which are expected to have positive wage effects. The local unemployment rate, part-time work and race are expected to have negative wage effects.

We use two alternative specifications of the weight variable, referred to as Model 1 and Model 2. (1) A linear variable, Body Mass Index (BMI), calculated as weight in kilograms divided by height in meters squared, tests whether "thinner is always better". We expect that the BMI coefficient in Model 1 will be negative. (2) $\mathrm{BMI}$ and $\mathrm{BMI}^{2}$ tests whether wage penalties only exist at higher weight levels, and allows the data to indicate the weight at which penalties

\footnotetext{
${ }^{5}$ We find evidence that wages and obesity are simultaneously determined, using the Hausman endogeneity test Pindyck and Rubenfeld, 1981 ). However, the substantive results and conclusions (i.e., sign, magnitude and statistical significance) do not change when a single equation model is used, so the results from the single equation model are reported.
} 
begin. We expect the BMI coefficient to be positive, and $\mathrm{BMI}^{2}$ coefficient to be negative in Model 2.

\section{RESULTS}

The estimated coefficients of the weight variables in the wage equations are reported in Table III. (The estimated coefficients of all variables are reported in the appendix.) The model is estimated separately for men and women, all races combined, and then separately for whites and blacks.

\section{INSERT TABLE III HERE}

The results largely conform to expectations. For women, Model 1 produces the strongest results. The estimated effect of the linear relative weight variable (BMI in Model 1) is negative and highly statistically significant for women when the data for all races are pooled. When the model is estimated separately by race, the negative effect of BMI remains highly significant (and slightly larger) for white women, but is marginally significant (at the. 10 level) and almost half the size for black women. BMI and $\mathrm{BMI}^{2}$ are resoundingly non-significant for women in Model 2. For women, economically as well as socially, thinner is always better, no matter how thin you already are.

The point estimates of the effect of BMI are fairly modest, but meaningful. For white women the .014 estimate indicates that a one-unit increase in BMI leads to a 1.4 percent decline in wages. For a woman of average height ( 5 feet 4 inches), a one-unit increase is equivalent to about 6 pounds. (For shorter women, the weight increase is smaller, and for taller women the weight increase is larger). In Table IV we report the percentage change in wages that our coefficient estimates predict will result when an individual's weight goes from standard to mild obesity or standard to morbid obesity, using the BMI values reported in Table I. 


\section{INSERT TABLE IV HERE}

Our estimates indicate that the wages of mildly obese white women are 5.8 percent lower than their standard weight counterparts, and wages of morbidly obese white women are 20.0 to 24.1 percent lower, depending on the definition of morbid obesity used. Large differences in weight relative to height are observed. BMI ranges from 11.4 to 49.0 for women in our sample. These differences yield substantial wage penalties for women,

In contrast, the estimated effect of the linear BMI variable (Model 1) on men's wages is significant (at the .05 level) and positive when the data for whites and blacks are pooled, as well as for black men, but falls far short of statistical significance for white men. The strongest results for men are obtained using Model 2, which allows the wage effect of relative weight to differ over the weight range. The $\mathrm{BMI}$ coefficient is positive, the $\mathrm{BMI}^{2}$ coefficient is negative, and both are highly significant for both white and black men. Using the Model 2 coefficients, we estimate that men who are mildly obese experience a wage premium (7. 1 percent for white men, and 16.0 percent for black men) compared to their standard weight counterparts. Remarkably, men do not experience a wage penalty until their weight exceeds standard weight by more than 100 pounds. White men whose weight is 100 pounds over standard have estimated wages that are 2.7 percent higher than their standard weight counterparts, and the wages of black men who are 100 pounds overweight have wages that are 21.8 percent higher. Men only experience wage penalties at the very highest weight levels. The wages of white men whose weight is 100 percent over standard for their height are 19.6 percent lower, and those of black men are 3.5 percent lower than their standard weight counterparts. White women suffer a greater wage penalty for mild obesity (20 percent over standard weight) than black men do for weight that is 100 percent over standard weight. 
These results are noteworthy for a number of reasons. We explicitly control for whether health limits the kind or amount of work the respondent can do, thus presumably eliminating the possibility that detrimental health or disability effects of obesity are the cause of the weight wage differential. We estimate the effect of body weight over the entire weight range, and find that women experience a wage penalty at weight levels far below morbid obesity but men do not. This suggests that the wage differential for women is driven by social norms that give strong preference to thinness, and stigmatize women who are overweight. If these differentials were the result of our inability to completely control for productivity differences between the obese and non-obese, they would be similar across genders. It is unlikely that mild obesity impairs women's productivity, but not men's. Any departure from a very slim "ideal" leads to wage penalties for women. Clearly this discrimination lies outside the purview of the ADA. On the other hand, the wage penalties experienced by men occur only at weight levels that may be protected by the ADA.

An important unanswered question is why white women experience weight-based wage penalties that are so much larger and more precisely estimated than black women. This difference is particularly puzzling, given that average weight for height is considerably higher for black women than for white women. This question warrants further investigation.

\section{CONCLUSIONS}

Our review of the ADA clearly indicates that only morbid obesity is potentially a protected status under the "perceived disability" theory. Our empirical estimates suggest that the weight-based discrimination which men experience may be legally protected, but the weightbased discrimination that women experience is largely unprotected. There is an extremely small number of morbidly obese individuals in our sample: 30 women and 5 men. These numbers are 
consistent with population statistics, and serve to underscore how severely limited legal protection against weight-based discrimination is under the ADA. In light of these findings, the current legality of weight-related appearance standards under both the ADA and Title VII is troubling. But an alternative analysis under Title VII holds some promise.

There is a much older body of case law under Title VII challenging employer weight limits, most notably in the airline industry. Challenges based on disparate impact theory have generally failed (Leonard v. National Airlines, 1977). Weight limits have been upheld as a valid appearance standard (ALPA v. United Airlines, 1979). "[The] district court ... could, on the basis of personal experience ... take judicial notice that in southern Florida airline's flight attendants enjoyed a reputation for competence as well as good looks" (Leonard v. National Airlines). Arguably, a "gender-plus" analysis under Title VII is more relevant to the nature of weight-based wage penalties that women experience. When women plaintiffs have been able to prove that weight limits were applied differentially based on gender, they have been successful (e.g., Laffey v. Northwest Airlines, 1973; ALPA v. United Airlines, 1979). Weight limits need not be written policy to be actionable under Title VII (EEOC Decision No. 71-1418 (1971) CCH EEOC Decisions para 6223). However, in the absence of a formal rule, it is far more difficult to obtain evidence that a weight criterion is applied systematically differently to men and women. The difficulty of obtaining such evidence could limit the practical utility of this approach. 


\section{BIBLIOGRAPHY}

Air Line Pilots Assoc. et al., v. United Airlines 480F. Supp. 1107(DC E.NY 1979).

Alessi, D.F. and Anthony, W.A. (1969). The Uniformity of Children's Attitudes Toward Physical Disabilities. Exceptional Children, 35, 543-545.

Allon, N. (1982) The Stigma of Overweight in Everyday Life. In B.B. Woman (Ed.), Psychological Aspects of Obesity. New York: Van Norstrand-Reinbold.

Averett, S. and Korenman, S. (1996). The Economic Reality of The Beauty Myth. Journal of Human Resources, 31, 304-330.

Barlow, C.E., Kohl 111, H.W., Gibbons, L.W., Blair, S.N. (1995). Physical Fitness, Mortalit and Obesity. International Journal of Obesity, 19 (Suppl 4), S41 -S44.

Berkow, R. et al. (Eds.) (1992). The Merck Manual of Diagnosis and Therapy, 16th ed. Rahway, N.J.: Merck.

Blair, S.N., Kohl 111, H.W., Barlow, C.E., Paffenbarger, R.S., Gibbons, L.W., and Macera, C.A. (1995). Changes in Physical Fitness and All-Cause Mortality: A Prospective Study of Healthy and Unhealthy Men. Journal of the American Medical Association, 273, 1093-1098.

Bryant v. Troy Auto Parts Warehouse 6 AD Cases 1474 (DC SInd 1997).

Bureau of National Affairs (1995). BNA's Americans with Disabilities Act Manual, See. 902, Definition of the Term 'Disability', 70:1135-1139.

Callaway, C.W. (1987). Women's Health: Nutrition. Obesity. Public Health Reports Supplement, July-August: 26-29.

Cassista v. Community Foods, Inc. 2 AD Cases 1188 (Calif SupCt 1993).

Civil Service Commission v. Pennsylvania Human Relations Commission 2 AD Cases 1345 (Pa SupCt 1991).

Cook v. State of Rhode Island, 2 AD Cases 1476 (CA 1, 1993).

Council on Scientific Affairs (1988). Treatment of Obesity in Adults. Journal of the American Medical Association, 260, Nov. 4,2547-2551.

Crandall, C. and Biernat, M. (1990). The Ideology of Anti-Fat Attitudes. Journal of Applied Social Psychology, 20, 227-243. 
Crocker, J., B. Cornwell, and Major, B. (1993) The Stigma of Overweight: Affective Consequences of Attributional Ambiguity. Journal of Personality and Social Psychology, 64,60-70.

DeJong, W. (1980). The Stigma of Obesity: The Consequences of Naive Assumptions Concerning the Causes of Physical Deviance. Journal of Health and Social Behavior, 21, 75-87.

EEOC v. Texas Bus Lines, 5 AD Cases 878 (DC STexas 1996).

Gaesser, G.A. Big Fat Lies: Obesity, Health and Metabolic Fitness. On-line at Mesomorphosis.com.

Garcia, J. (1995). Weight-Based Discrimination and the Americans with Disabilities Act: Is There an End in Sight? Hofstra Labor Law Journal, 13, 209-237.

Goffman, E. (1963). Stigma: Notes on the Management of Spoiled Identity. N.J.: Prentice-Hall.

Gortmaker, S.L., Must, A., Perrin, J.M., Sobol, A.M., and Dietz, W.H. (1993). Social and Economic Consequences of Overweight in Adolescence and Young Adulthood. New England Journal of Medicine, 329, Sept. 30, 1008-12.

Hamermesh, D. and Biddle, J. (1994). Beauty and the Labor Market. American Economic Review 84, 1174-1194.

Hartnett, P. (1993). Nature or Nurture, Lifestyle or Fate: Employment Discrimination against Obese Workers. Rutgers Law Journal, 24, 807-845,

Hauser, R. M. and Warren, J. R. (1996). Socioeconomic Indexes for Occupations: A Review, Update, and Critique. Center for Demography and Ecology Working Paper No. 96-0 1, University of Wisconsin-Madison.

Kuss, C.L. (1996). Absolving a Deadly Sin: A Medical and Legal Argument for Including Obesity as a Disability under the Americans with Disabilities Act. Journal of Contemporary Health Law and Policy, 12, 563-605.

Laabs, J. (1995). Does Image Matter? Personnel Journal, 48-6 1.

Laffey v. Northwest Airlines 366 F. Supp. 763 (1973).

Larkin, J. C. and Pines, H. A. (1979). No Fat Persons Need Apply. Sociology of Work and Occupations, 6, 312-327.

Leonard v. National Airlines 434 F. Supp. 269 (DC SD Fla 1977). 
Loh, E. S. (1993). The Economic Effects of Physical Appearance. Social Science Quarterly 74, 419-438.

McAdams, T., Moussavi, F. and Klassen, M. (1992). Employee Appearance and the Americans with Disabilities Act: An Emerging Issue? Employee Responsibilities and Rights Journal, 5, 323-338.

Metropolitan Life Foundation (1983). Statistical Bulletin, 64, 2-9.

Must, A., Dallal, G.E. and Dietz, W.H. (1991). Reference Data for Obesity: 85th and 95th Percentiles of Body Mass Index (Weight/Height ${ }^{2}$ ) and Triceps Skinfold Thickness. American Journal of Clinical Nutrition, 53, 839-846, and Erratum (1991), 54, 773.

National Institutes of Health (1985). Health Implications of Obesity. NIH Consensus Development Conference Statement Online, 5(9), 1-7.

Nedderv. Rivier College 5 AD Cases 1691 (DC NH 1996).

Paffenbarger, R.S., Hyde, R.T., Wing, A.L., Lee, I-M., Jung, D.L. and Kampert, J.B. (1993). New England Journal of Medicine, 328, 538-545.

Paul, R. and Townsend, J. (1995). Shape Up or Ship Out? Employment Discrimination Against the Overweight. Employee Responsibilities and Rights Journal, 8, 133-145.

Pindyck, R.S. and Rubenfeld, D.L. (1981) Econometric Models and Economic Forecasts New Y York: McGraw Hill.

Polesnak v. R. H. Management Systems 6 AD Cases 417 (DC WPa 1997).

Register, C.A. and Williams, D.R. (1990). Wage Effects of Obesity Among Young Workers. Social Science Quarterly, 71, 130-41.

Richardson, S.A., Hastorf, A., Goodman, N. and Dornbush, S.(1961). Cultural Uniformity in Reaction to Physical Disabilities. American Sociological Review, 26, 241-247.

Rothblum, E.D. (1994). I'll Die for the Revolution but Don't Ask me to Diet. In P. Fallon, et al., Eds. Feminist Perspectives on Eating Disorders, 54, 53-74.

Sargent, J.D. and Blanchflower, D.G. (1994) Obesity and Stature in Adolescence and Earnings in Young Adulthood. Archives of Pediatric Adolescent Medicine, 148, 681-687.

Sobal, J. and Stunkard, A.J. (1989). Socioeconomic Status and Obesity: A Review of the Literature. Psychological Bulletin, 105, 260-275.

State Division of Human Rights v. Xerox Corp. 1 AD Cases 753 (NY Ct App 1985). 
Troiano, R.P., Frongillo, E.A., Sobal, J. and Levitsky, D.A. (1996). The Relationship between Body Weight and Mortality: A Quantitative Analysis of Combined Information from Existing Studies. International Journal of Obesity, 20, 63 -75.

Tudyman v. United Airlines 608 F. Supp 7391 AD Cases 664 (DC C Calif 1984).

Ziolkowski, S.M. (1994). The Status of Weight-Based Employment Discrimination Under the Americans with Disabilities Act after Cookv. Rhode Island. Boston University Law Review, 74, 667-686. 
Table I. Alternative Definitions of Obesity, in Body Mass Index and Pounds (in parentheses) by Gender, Illustrative Heights

\begin{tabular}{|c|c|c|c|c|}
\hline & \multicolumn{2}{|c|}{ Woman 5'5" } & \multicolumn{2}{c|}{ Man 6' } \\
\hline & "Standard" & "Obese" & "Standard" & "Obese" \\
\hline Met Life 1983 & 21.1 & 25.3 & 21.7 & 26.4 \\
"mild obesity" & $(127)$ & $(152.4)$ & $(162)$ & $(194)$ \\
\hline NHANES-I & & 26.6 & & 27.8 \\
$85^{\text {th }}$ percentile & & $(160)$ & & $(205)$ \\
\hline NHANES-II & $(111-142)$ & 28.8 & $(148-184)$ & 30.9 \\
95 $5^{\text {th }}$ percentile & & $(173.4)$ & & $(228.4)$ \\
\hline Morbid obesity & & $37.0 / 40.8$ & & $35.5 / 43.9$ \\
$(100$ lbs. Over std.)/ & & $(223 / 246)$ & & $(262 / 324)$ \\
100\% over std. & & & & \\
\hline Max. difference & & $61 \%$ & & $67 \%$ \\
in definitions & & $(93.6)$ & & $(130)$ \\
\hline
\end{tabular}


Table II. Variable Names and Definitions

\begin{tabular}{|l|l|}
\hline Variable Name & \multicolumn{1}{|c|}{ Variable Definition } \\
\hline BMI & Body Mass Index $=\frac{\text { weight }(\mathrm{kg})_{\text {height }}(\mathrm{m})}{\text { in }^{2}}$ \\
\hline BMI $^{2}$ & BMI squared. \\
\hline LNWAGE & Natural log of the hourly wage rate. \\
\hline AFQT & Percentile score on the Armed Forces Qualification Test. \\
\hline HLTHLMT & Dummy $=1$ if health limits the kind or amount of work respondent can do. \\
\hline FSEI/MSEI & Gender-specific socioeconomic index of occupations. \\
\hline ED & Highest grade completed as of the 1988 survey. \\
\hline EXPER & Number of weeks worked in previous 4 years. \\
\hline TENURE & Number of weeks worked for current employer on primary job. \\
\hline PT-TIME & Dummy=1 if worked less than 35 hours/week. \\
\hline BLACK & Dummy=1 if race is African-American. \\
\hline OTHER & Dummy=1 if race is not white or African-American. \\
\hline METRO & Dummy=1 if resides in Standard Metropolitan Statistical Area. \\
\hline CAPINT & $\begin{array}{l}\text { Dummy=1 if works in capital-intensive industry (agriculture, mining, } \\
\text { construction, manufacturing, transportation or utilities. }\end{array}$ \\
\hline UNION & Dummy=1 if primary job is covered by a collective bargaining agreement. \\
\hline LGFIRM & Dummy=1 if primary job is in a firm with 500 or more employees. \\
\hline LOCALUE & Local area unemployment rate. \\
\hline REGION & Dummies=1 if residence in Northeast, North Central or West. \\
\hline
\end{tabular}


Table III. Least Squares Estimates ${ }^{\mathrm{a}}$ of Relative Weight (BMI) on Log Wages, By Gender and Race

(Standard Errors in Parentheses)

\begin{tabular}{|c|c|c|c|}
\hline Race and Gender & Model 1 & \multicolumn{2}{|c|}{ Model 2 } \\
\hline & BMI & BMI & $\mathrm{BMI}^{2}$ \\
\hline All Women & $-.011^{* * *}$ & -.001 & -.0002 \\
& $(.003)$ & $(.016)$ & $(.0003)$ \\
\hline White Women & $-.014^{* * *}$ & -.016 & .00004 \\
& $(.003)$ & $(.019)$ & $(.00035)$ \\
\hline Black Women & $-.008^{*}$ & .014 & -.0004 \\
& $(.005)$ & $(.032)$ & $(.0005)$ \\
\hline All Men & $.0066^{* *}$ & $.089^{* * *}$ & $-.0015^{* * *}$ \\
& $(.0027)$ & $(.021)$ & $(.0004)$ \\
\hline White Men & .003 & $.082^{* * *}$ & $-.0014 * * *$ \\
& $(.003)$ & $(.025)$ & $(.0004)$ \\
\hline Black Men & $.016^{*}$ & $.123 * * *$ & $-.0019 * *$ \\
& $(.006)$ & $(.049)$ & $(.0009)$ \\
\hline
\end{tabular}

${ }^{\mathrm{a} C}$ Controls: AFQT, HLTHLMT, FSEI or MSEI, ED, EXPER, TENURE, TENURE2 ${ }^{2}$ METRO, CAPINT, UNION, LOCALUE, PT-TIME, BLACK, OTHER, region dummies.

***indicates statistical significance at .01 level.

** indicates statistical significance at .05 level.

* indicates statistical significance at .10 level. 
Table IV. Predicated Percentage Change in Wage Due to Change in Weight Compared to "Standard" Weight

\begin{tabular}{|c|c|c|c|}
\hline Gender/Race & $\begin{array}{c}\text { Standard to Mild } \\
\text { Obesity }\end{array}$ & $\begin{array}{c}\text { Standard to Morbid } \\
\text { Obesity (100 pounds } \\
\text { over standard) }\end{array}$ & $\begin{array}{c}\text { Standard to Morbid } \\
\text { Obesity (100\% over } \\
\text { standard) }\end{array}$ \\
\hline White Women $^{\mathrm{c}}$ & $-5.8 \%$ & $-20.0 \%$ & $-24.1 \%$ \\
\hline Black Women $^{\mathrm{c}}$ & $-3.3 \%$ & $-11.9 \%$ & $-14.6 \%$ \\
\hline White Men $^{\mathrm{d}}$ & $+7.1 \%$ & $+2.7 \%$ & $-19.6 \%$ \\
\hline Black Men $^{\mathrm{d}}$ & $+16.0 \%$ & $+21.8 \%$ & $-3.5 \%$ \\
\hline
\end{tabular}

${ }^{\mathrm{c} C a l c u l a t e d}$ as $\exp \left(\beta_{1} * \Delta \mathrm{BMI}\right)-1$ using Model 1 coefficient estimates.

${ }^{\mathrm{d}}$ Calculated as $\exp \left[\left(\beta_{1} * \Delta \mathrm{BMI}\right)+\left(\beta_{2} * \Delta \mathrm{BMI}^{2}\right)\right]-1$ using Model 2 coefficient estimates. where: exp is the inverse of the natural $\log \left(\mathrm{e}^{\mathrm{x}}\right)$.

$\beta_{1}=$ estimated coefficient of BMI.

$\beta_{2}=$ estimated coefficient of $\mathrm{BMI}^{2}$.

$\triangle \mathrm{BMI}=\mathrm{BMI}$ obese $-\mathrm{BMI}$ standard using the BMIs of standard weight and alternative definitions of obesity from Table I. 
TABLE A-I. Least Squares Estimates of Model 1 for Women, Dependent Variable: LnWage (standard errors in parentheses)

\begin{tabular}{|c|c|c|c|}
\hline$\underline{\text { Variable }}$ & All Women & White Women & Black Womer \\
\hline ED & $\begin{array}{c}.039 * * * \\
(008)\end{array}$ & $\begin{array}{c}.045 * * * \\
(.010)\end{array}$ & $\begin{array}{c}.027 \\
(.018)\end{array}$ \\
\hline EXPER & $\begin{array}{l}.433 * * \\
(.015)\end{array}$ & $\begin{array}{c}.460^{* * *} \\
(018)\end{array}$ & $\begin{array}{c}.382 * * * \\
(030)\end{array}$ \\
\hline TENURE & $\begin{array}{c}.119 * * * \\
(.016)\end{array}$ & $\begin{array}{c}.118 * * * \\
(.019)\end{array}$ & $\begin{array}{c}.115 * * * \\
(.033)\end{array}$ \\
\hline TENURE $^{2}$ & $\begin{array}{c}-.010 * * * \\
(.002)\end{array}$ & $\begin{array}{c}-.010 * * * \\
(002)\end{array}$ & $\begin{array}{c}-.010^{* * * *} \\
(003)\end{array}$ \\
\hline AFQT & $\begin{array}{c}.004 * * * \\
(.001)\end{array}$ & $\begin{array}{c}.003 * * * \\
(.001)\end{array}$ & $\begin{array}{c}.006 * * * \\
(002)\end{array}$ \\
\hline HLTHLMT & $\begin{array}{c}-.114^{*} \\
(.060)\end{array}$ & $\begin{array}{l}-.008 \\
(.071)\end{array}$ & $\begin{array}{c}-.362 * * * \\
(.114)\end{array}$ \\
\hline BMI & $\begin{array}{c}-.011 * * * \\
(.003)\end{array}$ & $\begin{array}{c}-.014 * * * \\
(.003)\end{array}$ & $\begin{array}{l}-.008^{*} \\
(.005)\end{array}$ \\
\hline FSEI & $\begin{array}{c}.008 * * * \\
(.001)\end{array}$ & $\begin{array}{c}.007 * * * \\
(.001)\end{array}$ & $\begin{array}{c}.012 * * * \\
(.002)\end{array}$ \\
\hline METRO & $\begin{array}{c}.093^{* * * *} \\
(.031)\end{array}$ & $\begin{array}{l}.085 * * \\
(.035)\end{array}$ & $\begin{array}{l}.124 * \\
(.074)\end{array}$ \\
\hline CAPINT & $\begin{array}{c}.164 * * * \\
(.032)\end{array}$ & $\begin{array}{c}.128 * * * \\
(.38)\end{array}$ & $\begin{array}{c}.277 * * * \\
(.068)\end{array}$ \\
\hline UNION & $\begin{array}{c}.154 * * * \\
(.038)\end{array}$ & $\begin{array}{c}.159 * * * \\
(.049)\end{array}$ & $\begin{array}{l}.159 * * \\
(.066)\end{array}$ \\
\hline LOCALUE & $\begin{array}{c}-.065^{* * *} \\
(.016)\end{array}$ & $\begin{array}{c}-.054 * * * \\
(.019)\end{array}$ & $\begin{array}{c}-.107 * * * \\
(.037)\end{array}$ \\
\hline PT-TIME & $\begin{array}{c}-.709 * * * \\
(.032)\end{array}$ & $\begin{array}{c}-.705 * * * \\
(.037)\end{array}$ & $\begin{array}{c}-.677 * * * \\
(.072)\end{array}$ \\
\hline BLACK & $\begin{array}{c}.020 \\
(036)\end{array}$ & --- & -- \\
\hline OTHER & $\begin{array}{l}* 047 \\
(.065)\end{array}$ & & - \\
\hline LGFIRM & $\begin{array}{c}.119 * * * * \\
(.035)\end{array}$ & $\begin{array}{c}.135 * * * \\
(.044)\end{array}$ & $\begin{array}{l}.030 \\
(.067)\end{array}$ \\
\hline NORTHEAST & $\begin{array}{c}.108^{* * * *} \\
(.037)\end{array}$ & $\begin{array}{c}.070 \\
(.044)\end{array}$ & $\begin{array}{l}.134 * \\
(.080)\end{array}$ \\
\hline NORTHCENTRAL & $\begin{array}{l}-.024 \\
(.035)\end{array}$ & $\begin{array}{l}-.060 \\
(040)\end{array}$ & $\begin{array}{c}.103 \\
(.081)\end{array}$ \\
\hline WEST & $\begin{array}{l}.069 * \\
(038)\end{array}$ & $\begin{array}{c}.051 \\
(.044)\end{array}$ & $\begin{array}{c}.114 \\
(106)\end{array}$ \\
\hline CONSTANT & $\begin{array}{c}7.024 * * * \\
(0.127)\end{array}$ & $\begin{array}{c}7.001 * * * \\
(0.151)\end{array}$ & $\begin{array}{c}7.177 * * * \\
(0.277)\end{array}$ \\
\hline $\mathrm{R}^{2}$ & .534 & .541 & .527 \\
\hline $\mathrm{N}$ & 3,208 & 2,277 & 770 \\
\hline
\end{tabular}


Table A-II. Least Squares Estimates of Model 2 for Men, Dependent Variable: LnWage (standard errors in parentheses)

\begin{tabular}{|c|c|c|c|}
\hline \multirow{3}{*}{$\begin{array}{c}\text { Variable } \\
\text { ED }\end{array}$} & All Men & White Men & Black Men \\
\hline & $.033 * * *$ & $.024 * * *$ & $.062 * * *$ \\
\hline & $(.006)$ & $(.007)$ & $(.016)$ \\
\hline \multirow[t]{2}{*}{ EXPER } & $.355^{* * *}$ & $.381 * * *$ & $.263 * * *$ \\
\hline & $(.014)$ & $(.017)$ & $(.029)$ \\
\hline \multirow[t]{2}{*}{ TENURE } & $.097 * * *$ & $.082 * * *$ & $.130 * * *$ \\
\hline & $(.012)$ & $(.014)$ & $(.030)$ \\
\hline \multirow[t]{2}{*}{ TENURE $^{2}$} & $-.007 * * *$ & $-.006 * * *$ & $-.009 * * *$ \\
\hline & $(.001)$ & $(.001)$ & $(.003)$ \\
\hline \multirow[t]{2}{*}{ AFQT } & $.003 * * *$ & $.003 * * *$ & $.004 * * *$ \\
\hline & $(.001)$ & $(.001)$ & $(.001)$ \\
\hline \multirow[t]{2}{*}{ HLTHLMT } & $-.100 *$ & -.038 & $-.245^{*}$ \\
\hline & $(.058)$ & $(.065)$ & $(.136)$ \\
\hline \multirow[t]{2}{*}{ BMI } & $.089 * * *$ & $.082 * * *$ & $.123 * * *$ \\
\hline & $(.021)$ & $(.025)$ & $(.049)$ \\
\hline \multirow[t]{2}{*}{$\mathrm{BMI}^{2}$} & $-.0015^{* * *}$ & $-.0014 * * *$ & $-.0019 * *$ \\
\hline & $(.0004)$ & $(.0004)$ & $(.0009)$ \\
\hline \multirow[t]{2}{*}{ MSEI } & $.011 * * *$ & $.011 * * *$ & $.011 * * *$ \\
\hline & $(.001)$ & $(.001)$ & $(.002)$ \\
\hline \multirow[t]{2}{*}{ METRO } & $.077 * * *$ & $.091 * * *$ & .091 \\
\hline & $(.025)$ & $(.027)$ & $(.065)$ \\
\hline \multirow[t]{2}{*}{ CAPINT } & $.135 * * *$ & $.109 * * *$ & $.148 * * *$ \\
\hline & $(.022)$ & $(.025)$ & $(.050)$ \\
\hline \multirow[t]{2}{*}{ UNION } & $.184 * * *$ & $.186^{* * *}$ & $.209 * * *$ \\
\hline & $(.029)$ & $(.034)$ & $(.060)$ \\
\hline \multirow[t]{2}{*}{ LOCALUE } & $-.042 * * *$ & $-.028 *$ & $-.093 * *$ \\
\hline & $(.013)$ & $(.014)$ & $(.038)$ \\
\hline \multirow[t]{2}{*}{ PT-TIME } & $-.755^{* * *}$ & $-.806 * * *$ & $-.650 * * *$ \\
\hline & $(.039)$ & $(.046)$ & $(.085)$ \\
\hline BLACK & $-.090 * * *$ & - & - \\
\hline \multirow{2}{*}{ OTHER } & $\begin{array}{l}(.029) \\
-.019\end{array}$ & $\overline{1}$ & 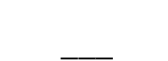 \\
\hline & $(.047)$ & & \\
\hline \multirow[t]{2}{*}{ LGFIRM } & .020 & .049 & -.031 \\
\hline & $(.031)$ & $(.037)$ & $(.068)$ \\
\hline \multirow[t]{2}{*}{ NORTHEAST } & $.083 * * *$ & $.129 * * *$ & .001 \\
\hline & $(.031)$ & $(.035)$ & $(.073)$ \\
\hline \multirow[t]{2}{*}{ NORTHCENTRAL } & -.033 & .023 & $-.236 * * *$ \\
\hline & $(.031)$ & $(.031)$ & $(.075)$ \\
\hline \multirow[t]{2}{*}{ WEST } & $.075 * *$ & $.089 * *$ & .048 \\
\hline & $(.031)$ & $(.034)$ & $(.100)$ \\
\hline \multirow[t]{2}{*}{ CONSTANT } & $6.099 * * *$ & $6.233 * * *$ & $5.453 * * *$ \\
\hline & $(0.301)$ & $(0.350)$ & $(0.687)$ \\
\hline $\mathrm{R}^{2}$ & .49 & .48 & .44 \\
\hline $\mathrm{N}$ & 3,393 & 2,363 & 801 \\
\hline
\end{tabular}

